\title{
地下連続壁用低発熱高流動コンクリートの 特性に関する研究
}

\author{
大友 健*1 ・田辺 清*2 ・中川 修*2 ・松木田正義*3
}

\begin{abstract}
概 要 低発熱セメントと高性能 AE 減水剂を組み合わせて使用した地下連続壁用低発熱高流動コンクリートを対象として, 結合材の種類および高性能 AE 減水剂の種類あるいは配合・製造上の要因がコンクリートの性質に及ぼす影響を検討した。また ポンプ圧送がコンクリートの性質に及ぼす影響について評価した。この結果, 以下のことが明らかとなった。ポリカルボン酸エー テル系高性能 $\mathrm{AE}$ 減水剂を使用したコンクリートは, $\beta$-ナフタリンスルフォン酸系を使用したものと比べて変形速度が大きく, 一定の流動性を保持した後の自立時間および凝結時間が早くなる。また圧縮強度も大きくなる傾向にある。高性能 $\mathrm{AE}$ 減水剤中 の架橋ポリマー量の調整により, コンクリートの流動性を所要時間確保することができる。ポンプ圧送することによりコンクリー トの粘性は低下する。スランプフローがロスするのは, 圧送中のコンクリートのせん断変形により骨材を含む微粒子が破砕され, この破面に高性能 AE 減水剂が吸着することで, 流動性の保持に寄与する実質の高性能 AE 減水剤量が減少することによると考 えられる。
\end{abstract}

キーワード : 地下連続壁, 低発熱セメント, 高性能 $\mathrm{AE}$ 減水剂, 流動性, 凝結, ポンプ圧送, スランプフローロス, 粒度分布

\section{1.はじめに}

大規模な地下連続壁に使用するコンクリートとして は, 現在, 材齢 91 日の設計基準強度が $360 \sim 370 \mathrm{kgf} /$ $\mathrm{cm}^{2}$ で配合強度が $540 \mathrm{kgf} / \mathrm{cm}^{2}$ 以上のものが主流と なってきている。また温度ひびわれの低減のために低発 熱セメントを適用することも一般的となりつつある1)。

この種のコンクリートは, 充填性を向上させ安定液中 での流動距離を大きくすることができるように従来の連 壁コンクリートとは異なり高流動化（スランプ $24 \mathrm{~cm}$ 以上）される傾向にあり, コンクリートのコンシステン シーの管理をスランプフローで行なうことが多くなって きている。またコンクリートの品質仕様として, 流動性 の保持条件など従来の連壁コンクリートにない新しい性 能が要求されるようになってきた。その結果, コンク リートの性質自体が従来の地下連続壁用コンクリートと 比べて大きく異なる傾向にあると考えられる。

そこで, 本研究では, 低発熱セメントと高性能 $\mathrm{AE}$ 減水剂を組み合わせて使用した地下連続壁用高流動コン クリートを対象として, 以下に示す内容について検討し た。

(1)結合材の種類と高性能 $\mathrm{AE}$ 減水剂の種類がフレッ

$* 1$ 大成建設(侏技術研究所（正会員）

*2 大成建設(侏東京支店 (正会員)

$* 3$ 大成建設(侏東京支店
シュコンクリートの性質やコンクリートの強度に及 ぼす影響

(2)高性能 $\mathrm{AE}$ 減水剂の使用量や単位水量の変化, 練 上り温度など配合・製造上の要因がコンクリートの 性質に及ぼす影響

(3)ポンプ圧送がフレッシュコンクリートの性質に及ぼ す影響

2. 研究の内容および実験の方法

\section{1 結合材の種類および高性能 $\mathrm{AE}$ 減水剂の種類が フレッシュコンクリートの性質や圧縮強度に及ぼ す影響}

(1) 検討内容

低発熱セメントには，水和発熱を抑制することを目的 として高炉スラグ微粉末やフライアッシュなどの混和材 が多量に混合されているが, 低発熱セメントの銘柄ごと にこの混和材の種類や混合比率は異なっている。一方, 高性能 $\mathrm{AE}$ 減水剂にも数種類の異なる主成分のものが 使用されており，さらに減水作用を主とする主成分にス ランプフロー保持成分を加えフレッシュコンクリートの 性質を調整することも行なわれている2)。

高流動コンクリートの流動性は, セメント等の粉体と 高性能 $\mathrm{AE}$ 減水剂との相互作用により得られることか ら, 結合材や高性能 $\mathrm{AE}$ 減水剂の特性が異なれば, コ ンクリートの流動性が変化することが考えられる。そこ 
で, まず，低発熱セメントの種類と高性能 $\mathrm{AE}$ 減水剤 の種類がフレッシュコンクリートの特性に及ぼす影響を 評価するための実験を行なった。

低発熱セメントに多量の高性能 $\mathrm{AE}$ 減水剂を使用す ることによりコンクリートの凝結時間が遅延する傾向に あることが知られている ${ }^{2)}$ 。これはコンクリートの流動 性の保持には好都合であるが, 一方で地下連続壁の構築 時には側圧の増大に影響を及ぼすものと考えられる。そ こで, フレッシュコンクリートの特性の検討において は, 流動性の他, その保持時間および凝結時間や自立特 性についても評価した。加えて, 高性能 $\mathrm{AE}$ 減水剂中 のスランプフロー保持成分の割合が流動性の保持やその 他の性質に及ぼす影響も検討した。

一方, この種の高流動コンクリートにおいては, 使用 する高性能 $\mathrm{AE}$ 減水剂の種類によって, 圧縮強度の発 現状況が異なることが報告されている3),4)。そこで, 高性能 $\mathrm{AE}$ 減水剂の種類が相違した場合のコンクリー 卜の圧縮強度の変化傾向を調べた。また使用する高性能 $\mathrm{AE}$ 減水剂の種類によって压縮強度が変化する原因を検 討するため, セメントペーストの初期水和発熱量の測定 および実際の圧縮試験で強度が異なる供試体を使用して の硬化コンクリートの結合水量の測定と水和生成物の種 類の調査を行なった。

(2) 結合材と高性能 AE 減水剂の種類

実験に使用した低発熱セメントおよび高性能 $\mathrm{AE}$ 減 水剂の種類と記号を表 -1 および表 -2 に示す。

\section{表 -1 結合材の種類}

\begin{tabular}{|c|c|c|c|c|}
\hline 結 合 材 種 類 & 記 号 & $\begin{array}{c}\text { 混合比率 } \\
\mathrm{OP}: \mathrm{BS}: \mathrm{FA}\end{array}$ & 比重 & $\begin{array}{l}\text { 比表面積 } \\
\left(\mathrm{cm}^{2} / \mathrm{g}\right)\end{array}$ \\
\hline (1)低発熱高炉セメントB種 & $\mathrm{MBB}$ & $44: 56:-$ & 3.00 & 3760 \\
\hline $\begin{array}{l}\text { (2) } 3 \text { 成分系低発熱セメンドト } \\
\text { (低発熱高炉セメ種フ } \\
\text { ライアッシュ } 20 \% \text { 混入) }\end{array}$ & FMBB & $35: 45: 20$ & 2.78 & 3630 \\
\hline (3) 3 成分系超低発熱セメント & $\mathrm{ULHC}$ & $20: 65: 15$ & 2.90 & 5220 \\
\hline \multicolumn{5}{|c|}{ 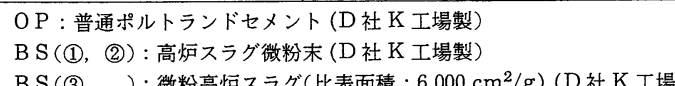 } \\
\hline
\end{tabular}

\section{表-2 高性能 $\mathrm{AE}$ 隇水剂の種類}

\begin{tabular}{|c|c|c|}
\hline 高性能 AE 減水剂種類 & 記 号 & 成 \\
\hline $\begin{array}{l}\text { (1)ポリカルボン酸エーテル系 } \\
\quad+\text { 架橋ボリマー }\end{array}$ & $\mathrm{SP}-\mathrm{P}$ & $\begin{array}{l}\text { 吕リカルボン酸エーテル系之 } \\
\text { 架橋ポリマーの複合体 (N社 } \\
\text { 呅) }\end{array}$ \\
\hline $\begin{array}{c}\text { (2) } \beta \text {-ナフタリンスルフォン } \\
\text { 酸系+活性持続ポリマー }\end{array}$ & $\mathrm{SP}-\mathrm{N}$ & $\begin{array}{l}\text { 変成リグニン, アルキルアリ } \\
\text { ルスルフォン酸および活性持 } \\
\text { 続ポリマー } \\
\text { ( 社製 })\end{array}$ \\
\hline $\begin{array}{c}\text { (3) } \beta \text {-ナフタリンスルフォン. } \\
\text { 酸系+徐放ポリマー }\end{array}$ & $\mathrm{SP}-\mathrm{NM}$ & $\begin{array}{l}\text { ポリアルキルアリルスルフォ } \\
\text { 酸塩と反応性高分子 (K 社 } \\
\text { 製) }\end{array}$ \\
\hline
\end{tabular}

ただし，各々の主成分に加えて架橋ポリマーや活性持続ポリマー量を 調整し，スランプフロー保持性能を調整した混和剤については, SP-P (1) 〜P (3), SP-N (1) 〜 N (3) と（）番号を付けて識別する。
結合材には, 低発熱高炉セメント B 種 (MBB), 3 成 分系低発熱セメント $(\mathrm{FMBB}$-低発熱高炉 $\mathrm{B}$ 種セメント にフライアッシュを内割りで $20 \%$ 混入したセメント) および 3 成分系超低発熱セメント (ULHC-ポルトラン ドセメントの割合を小さくし, 粉末度の小さい高炉スラ グ微粉末を多量に混合することで超低発熱化したセメン ト）を使用した。これらの低発熱セメントはいずれも気 中コンクリートとして多くの施工実績があるものであ る。

高性能 $\mathrm{AE}$ 減水剂には, ポリカルボン酸エーテル系 と $\beta$-ナフタリンスルフォン酸系を使用した。ポリカル ボン酸エーテル系 $(\mathrm{SP}-\mathrm{P})$ は, 架橋ポリマー量を調整 した 3 種類（架橋ポリマー量： SP-P (1) $<\mathrm{SP}-\mathrm{P}$ (2) $<\mathrm{SP}-\mathrm{P}(3)$, 架橋ポリマー量が大きいほどスランプ フロー保持性能が大きい）を, $\beta$-ナフタリンスルフォ ン酸系 $(\mathrm{SP}-\mathrm{N})$ については, 活性持続ポリマー量を調 整した 2 種類（活性持続ポリマー量 : $\mathrm{SP}-\mathrm{N}(1)>\mathrm{SP}-$ $\mathrm{N}$ (2), 活性持続ポリマー量が大きいほどスランプフ ロー保持性能が大きい）を使用した。 $\beta$-ナフタリンス ルフォン酸系については他のメーカーのもの (SPNM) も使用した。

\section{（3）コンクリート試験の配合ケースと実験項目}

実験(1)-1では, 表-3に示すように, 3 種類の低発熱 セメントとポリカルボン酸エーテル系および $\beta$-ナフタ リンスルフォン酸系の高性能 $\mathrm{AE}$ 減水剂をそれぞれ組 み合わせた 9 配合について, フレッシュコンクリートの 性質とコンクリートの圧縮強度の変化傾向を調べた。

実験(1)-2では, 表-4に示すように, 製造ロットの異

表-3 コンクリートの仕様, 配合および使用材料 (実験(1)-1)

\begin{tabular}{|c|c|c|c|c|c|c|c|c|}
\hline \multicolumn{9}{|c|}{$\begin{array}{l}\text { 配合強度 (材齢 } 91 \text { 日) }: 650 \mathrm{kgf} / \mathrm{cm}^{2} \\
\text { スランプフロ : } 65 \pm 5 \mathrm{~cm} \text {, 空気量 : } 2 \% \\
\text { スランプフロー }(3 \text { 時間後 }): 50 \mathrm{~cm} \text { 程度以上 } \\
\text { 粗骨材の最大寸法 }: 20 \mathrm{~mm} \text {, 単位粗骨材かさ容積 }: 0.6 \mathrm{~m}^{3} / \mathrm{m}^{3}\end{array}$} \\
\hline \multirow{2}{*}{$\begin{array}{l}\text { 結合材 } \\
\text { 種 }\end{array}$} & \multirow{2}{*}{$\begin{array}{l}W / C \\
(\%)\end{array}$} & \multirow{2}{*}{$\begin{array}{l}s / a \\
(\%)\end{array}$} & \multicolumn{4}{|c|}{ 单位量 $\left(\mathrm{kg} / \mathrm{m}^{3}\right)$} & \multirow{2}{*}{\begin{tabular}{|c|} 
混和剤 \\
種 類
\end{tabular}} & \multirow{2}{*}{$\begin{array}{l}\text { 使用量 } \\
(C \times \%)\end{array}$} \\
\hline & & & $W$ & $C$ & $S$ & $G$ & & \\
\hline MBB & 37 & 42.8 & 165 & 446 & 741 & 1029 & $\begin{array}{l}\mathrm{SP}-\mathrm{N}(1) \\
\mathrm{SP}-\mathrm{N}(2) \\
\mathrm{SP}-\mathrm{P}(1)\end{array}$ & $\begin{array}{l}2.7 \\
2.7 \\
2.1\end{array}$ \\
\hline FMBB & 33 & 41.0 & 160 & 485 & 689 & 1029 & $\begin{array}{l}\mathrm{SP}-\mathrm{N}(1) \\
\mathrm{SP}-\mathrm{N}(2) \\
\mathrm{SP}-\mathrm{P}(2)\end{array}$ & $\begin{array}{l}2.7 \\
2.7 \\
1.8\end{array}$ \\
\hline $\mathrm{ULHC}$ & 29 & 41.6 & 150 & 517 & 705 & 1029 & $\mid \begin{array}{l}\mathrm{SP}-\mathrm{N}(1) \\
\mathrm{SP}-\mathrm{N}(2) \\
\mathrm{SP}-\mathrm{P}(3)\end{array}$ & $\begin{array}{l}2.7 \\
2.7 \\
2.0\end{array}$ \\
\hline \multicolumn{9}{|c|}{ 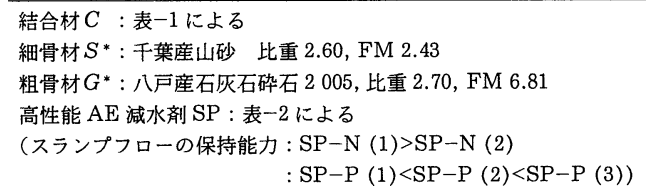 } \\
\hline
\end{tabular}


表-4 コンクリートの仕様，配合（実験(1)-2）

\begin{tabular}{|c|c|c|c|c|c|c|c|c|}
\hline \multicolumn{9}{|c|}{$\begin{array}{l}\text { 配合強度（材齢 } 91 \text { 日）: } 600 \mathrm{kgf} / \mathrm{cm}^{2} \\
\text { スランプフロー }: 65 \pm 5 \mathrm{~cm} \text {, 空気量 : } 2 \% \\
\text { スランプフロー }(3 \text { 時間後 }): 50 \mathrm{~cm} \text { 程度以上 }\end{array}$} \\
\hline \multirow{2}{*}{ 秸合材 } & \multirow{2}{*}{$\begin{array}{l}W / C \\
(\%)\end{array}$} & \multirow{2}{*}{$\begin{array}{l}s / a \\
(\%)\end{array}$} & \multicolumn{4}{|c|}{ 単位量 $\left(\mathrm{kg} / \mathrm{m}^{3}\right)$} & \multirow{2}{*}{$\begin{array}{l}\text { 混和剤 } \\
\text { 種 類 }\end{array}$} & \multirow{2}{*}{$\begin{array}{c}\text { 使用量 } \\
(C \times \%)\end{array}$} \\
\hline & & & $W$ & $C$ & $S$ & $G$ & & \\
\hline $\begin{array}{l}\text { FMBB } \\
\text { Lot (1) }\end{array}$ & 36.9 & 48.0 & 155 & 420 & 762 & 1010 & $\begin{array}{l}\text { SP-P(1) } \\
\text { SP-P(2) } \\
\text { SP-N } \\
\text { SP-NM }\end{array}$ & $\begin{array}{l}1.7 \\
1.6 \\
2.5 \\
2.5\end{array}$ \\
\hline $\begin{array}{l}\text { FMBB } \\
\text { Lot (2) }\end{array}$ & 36.9 & 48.0 & 155 & 420 & 762 & 1010 & $\begin{array}{l}\mathrm{SP}-\mathrm{P}(2) \\
\mathrm{SP}-\mathrm{N} \\
\mathrm{SP}-\mathrm{NM}\end{array}$ & $\begin{array}{l}1.8 \\
2.7 \\
2.7\end{array}$ \\
\hline
\end{tabular}

結合材 $C:$ フライアッシュ $20 \%$ 混入低発熱高炉セメント $\mathrm{B}$ 種 (OP : BS : FA=35: $45: 20$ )比重 2.78(ロット違い 2 種)

高性能 $\mathrm{AE}$ 減水剂 : 表-2による

（スランプフローの保持能力 : SP-P (1)<SP-P (2)

表-5 コンクリートの仕様, 配合 (実験(1)-3)

配合強度（材䶜 91 日）: $600 \mathrm{kgf} / \mathrm{cm}^{2}$

スランプフロー: $65 \pm 5 \mathrm{~cm}$, 空気量 : $2 \%$

\begin{tabular}{|c|c|c|c|c|c|c|c|c|}
\hline \multirow{2}{*}{ 結合材 } & \multirow{2}{*}{$\begin{array}{l}W / C \\
(\%)\end{array}$} & \multirow{2}{*}{$\begin{array}{l}s / a \\
(\%)\end{array}$} & \multicolumn{4}{|c|}{ 単位量 $\left(\mathrm{kg} / \mathrm{m}^{3}\right)$} & \multirow{2}{*}{$\begin{array}{l}\text { 混和剂 } \\
\text { 種 類 }\end{array}$} & \multirow{2}{*}{$\begin{array}{l}\text { 使用量 } \\
(C \times \%)\end{array}$} \\
\hline & & & $W$ & $C$ & $S$ & $G$ & & \\
\hline & 36.9 & 48.0 & 155 & 420 & 762 & 1010 & $\begin{array}{l}\mathrm{SP}-\mathrm{P}(1) \\
\mathrm{SP}-\mathrm{P}(2) \\
\mathrm{SP}-\mathrm{P}(3)\end{array}$ & $\begin{array}{l}1.7 \\
1.7 \\
1.7\end{array}$ \\
\hline
\end{tabular}

結合材 $C$ : フライアッシュ $20 \%$ 混入低発熱高炉セメント B 種 (OP : BS : FA=35: $45: 20$ ) 比重 2.78

高性能 $\mathrm{AE}$ 減水剂：ポリカルボン酸エーテル系と架橋ポリマー (スランプフローの保持能力 : SP-P (1) $<\mathrm{SP}-\mathrm{P}(2)<\mathrm{S}$ $\mathrm{P}-\mathrm{P}(3))$

なる 2 種類の 3 成分系低発熱セメントに対して 3 種類の 高性能 $\mathrm{AE}$ 減水剂を使用した 6 配合について，フレッ シュコンクリートの性質と圧縮強度の変化傾向を調へ た。

実験(1)-3 では，表-5 に示すように，ポリカルボン酸 エーテル系高性能 $\mathrm{AE}$ 減水剂中のスランプフロー保持 成分の割合を変化させた 3 配合について，フレッシュコ ンクリートの性質を調べた。

フレッシュコンクリートの性質については，各々の配 合ケースについて, 練上り後 3 時間までのスランプフ ローの経時変化と凝結硬化時間を測定した。これに加え て, 実験1)-1 ではスランプフロー停止時間（スランプ コーンを引き上げはじめてからコンクリートの変形が止 まるまでに要する時間）とコンクリートの自立時間（練 上りからコンクリートのスランプが $10 \mathrm{~cm}$ になるのに 要する時間）を測定した。実験(1)-3では，スランプフ ローの経時変化測定を練上り後 3 時間以降スランプフ ローが $30 \mathrm{~cm}$ となるまで継続して実施した。

スランプフロー停止時間の測定は, スランプフロー測 定時のコンクリートの変形速度を評価するために実施し たものである。変形速度は, スランプフローの先端の移
動距離をスランプフローの停止時間で除して, 平均変形 速度として表した。自立時間の測定は，コンクリートの 側圧の低下時間の遅早を評価するために実施したもので ある。これらの実験はすべて $20^{\circ} \mathrm{C}$ 温度条件で実施し た。

（4）セメントペーストの初期水和発熱量および硬化 コンクリートの水和反応に関する測定

高性能 $\mathrm{AE}$ 減水剂を添加したセメントペーストの初 期水和発熱量を測定した。結合材として 3 成分系低発熱 セメントを使用し，水結合材比 $36 \%$ のペーストに 3 種 類の高性能 $\mathrm{AE}$ 減水剂 $\mathrm{SP}-\mathrm{P}, \mathrm{SP}-\mathrm{N}, \mathrm{SP}-\mathrm{NM}$ (実験 (1)-2 に使用したものと同様の材料）を，コンクリート に使用した時にほぼ同程度のスランプフローの経時変化 特性を有する使用量で添加した（それぞれ結合材量の $1.6 \%, 2.5 \%, 2.3 \%)$ 。

測定には 6 点式微小熱量計（レスカ製）を使用し，試 験温度 $20^{\circ} \mathrm{C}$, 試料攪䢁時間 3 分間で, 接水後 168 時間 まで水和発熱量を測定した。

硬化コンクリートの結合水量の測定方法および水和生 成物の種類と量の調査方法の概要を図-1 に示す。 3 成 分系低発熱セメントを使用したコンクリートで高性能 $\mathrm{AE}$ 減水剂の種類以外が同様の配合の, 材齢 91 日にお ける強度測定後の供試体を使用して, 高性能 $\mathrm{AE}$ 減水 剂 ( $\mathrm{SP}-\mathrm{P}, \mathrm{SP}-\mathrm{N}, \mathrm{SP}-\mathrm{NM})$ の相違がコンクリートの 結合水量と水和生成物の種類に及ぼす影響を検討した。

\section{2 配合・製造上の要因がコンクリートの性質に及} ぼす影響

\section{(1) 検討内容}

高流動コンクリートでは, 必要な流動性の大部分を高 性能 $\mathrm{AE}$ 減水剂の効果により得ている。したがって一 般には，実際にコンクリートを製造・施工する上での結 合材や骨材など使用材料の特性の変動やこれに伴う流動 性の変化を, 高性能 $\mathrm{AE}$ 減水剂の使用量を調節するこ とにより制御することが行なわれている。そこで，ま ず, 高性能 $\mathrm{AE}$ 減水剂の使用量がフレッシュコンク リートの性質に及ぼす影響を検討した。

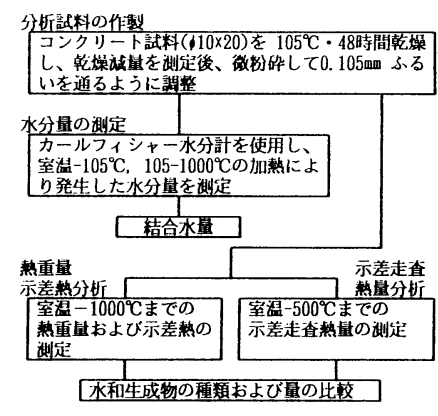

図-1＼cjkstart硬化コンクリートの分析方法 
一方, 連壁用のコンクリートは, 水結合材比が比較的 小さくなること, また高流動コンクリートであるため に，スランプで管理される領域のコンクリートと比較し て，骨材の表面水率のわずかな変動によって流動性が著 しく変化することが知られている。そこで, 細骨材の表 面水率が変化した場合のフレッシュコンクリートの性質 および圧縮強度の変化について検討した。

さらに, 高性能 $\mathrm{AE}$ 減水剂の効果には温度依存性が あることが知られており, また，練上りコンクリート温 度が同じ場合でも, 練混ぜ水に低温水を使用した場合 は, 一定の流動性を得るために必要な高性能 $\mathrm{AE}$ 減水 剂の使用量が多くなるという報告5)もある。したがっ て，ここではコンクリートの練上り温度がフレッシュコ ンクリートの性質に及ぼす影響を検討することに加え て, 練混ぜ水の温度が異なる場合の影響についても検討 した。

\section{（2）実験ケースと配合および実験項目}

各実験の内容を表-6に示す。結合材には 3 成分系低 発熱セメントを, 高性能 $\mathrm{AE}$ 減水剂にはポリカルボン 酸エーテル系を使用した。コンクリートの基本配合およ びその他の使用材料を表 -7 に示す。

実験(2)-1では, 単位水量を $155 \mathrm{~kg} / \mathrm{m}^{3}$ で一定とし, 高性能 $\mathrm{AE}$ 減水剂の使用量を単位結合材量の 1.45 $1.75 \%$ の範囲で変化させた場合のフレッシュコンク

表-6 実験の要因 (実験(2)

\begin{tabular}{|c|c|c|c|c|c|}
\hline 実験 & 検討内容 & 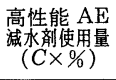 & $\begin{array}{l}\text { 単位水量 } \\
\left(\mathrm{kg} / \mathrm{m}^{3}\right)\end{array}$ & $\begin{array}{c}\text { 細骨材表面 } \\
\text { 水率変動 } \\
(\%)\end{array}$ & $\begin{array}{l}\text { 練上り温度 } \\
\left({ }^{\circ} \mathrm{C}\right) \text { (水温) }\end{array}$ \\
\hline (2) -1 & $\begin{array}{l}\text { 高性能 } \mathrm{AE} \\
\text { 減水剂使用 } \\
\text { 量 }\end{array}$ & $\begin{array}{l}1.45,1.5 \\
1.6,1.7 \\
1.75\end{array}$ & 155 & - & 20 \\
\hline \multirow{2}{*}{ (2) -2} & \multirow{2}{*}{$\begin{array}{l}\text { 単位水量の } \\
\text { 変 動* }\end{array}$} & 1.7 & $\begin{array}{l}150,155 \\
160,165\end{array}$ & $\begin{array}{l}-0.65,0 \\
+0.65,+1.3\end{array}$ & 20 \\
\hline & & 1.85 & $\begin{array}{c}150,155 \\
160\end{array}$ & $\begin{array}{l}-0.65,0 \\
+0.65\end{array}$ & 20 \\
\hline (2) -3 & 練上り’温度 & 1.6 & 155 & - & $\begin{array}{l}11,17(5) \\
13,20(20)\end{array}$ \\
\hline
\end{tabular}

* 細骨材の表面水率が変動したものとして単位水量を変化させた場合

表一7 コンクリートの仕様, 配合, 使用材料 (実験(2)

\begin{tabular}{|c|c|c|c|c|c|c|c|c|}
\hline \multicolumn{9}{|c|}{$\begin{array}{l}\text { 配合強度（材齢 } 91 \text { 日）: } 600 \mathrm{kgf} / \mathrm{cm}^{2} \\
\text { スランプフロー: } 65 \pm 5 \mathrm{~cm} \text {, 空気量 : } 2 \%\end{array}$} \\
\hline \multirow{2}{*}{$\begin{array}{l}\text { 結合材 } \\
\text { 種 類 }\end{array}$} & \multirow{2}{*}{$\begin{array}{l}W / C \\
(\%)\end{array}$} & \multirow{2}{*}{$\begin{array}{l}s / a \\
(\%)\end{array}$} & \multicolumn{4}{|c|}{ 単位量 $\left(\mathrm{kg} / \mathrm{m}^{3}\right)$} & \multirow{2}{*}{$\begin{array}{l}\text { 混和剂 } \\
\text { 種 類 }\end{array}$} & \multirow{2}{*}{$\begin{array}{l}\text { 使用量* } \\
(C \times \%)\end{array}$} \\
\hline & & & $W^{*}$ & C & $S$ & $G$ & & \\
\hline FMBB & 36.9 & 48.0 & 155 & 420 & 762 & 1010 & $\mathrm{SP}-\mathrm{P}$ & 1.7 \\
\hline
\end{tabular}

結合材 $C$ : フライアッシュ $20 \%$ 混入低発熱高炉セメント B 種 (OP : BS : FA=35: $45: 20$ ) 比重 2.78

細骨材 $S:$ 千葉産山砂 比重 2.60, FM 2.43

粗骨材 $G$ : 八戸産石灰石砕石 2005 , 比重 2.70, FM 6.81

高性能 $\mathrm{AE}$ 減水剂 : ポリカルボン酸エーテル系と架橋ポリマー

*単位水量および高性能 $\mathrm{AE}$ 減水剂使用量については, 実験の目 的により变化させた。
リートの性質の変化について検討した。練上りから 3 時 間までのスランプフローとスランプフローの経時変化量 および凝結時間を測定した。また，コンクリートのスラ ンプフローの停止時間を測定することで，スランプフ ロー試験時のコンクリートの平均変形速度を評価した。

実験(2)-2 では, 単位水量 $155 \mathrm{~kg} / \mathrm{m}^{3}$ の配合におい て, 細骨材の表面水量を-5 10 kg/m ${ }^{3}$ (表面水率で $-0.65 \sim 1.3 \%$ ）の範囲で変化させた場合について検討 した。ここで, 高性能 $\mathrm{AE}$ 減水剤の使用量を単位結合 材量の $1.7 \%$ と $1.85 \%$ の 2 種類とした。フレッシュコ ンクリートの性質として, 練上りから 3 時間までのスラ ンプフローとスランプフローの経時変化量および凝結時 間を測定した。また材齢 28 日における圧縮強度も測定 した。実験(2)-1 および実験(2)-2 の実験はすべて $20^{\circ} \mathrm{C}$ の温度条件下で実施した。

実験(3)-3 では, コンクリートの練上り温度を $12^{\circ} \mathrm{C}$ 程 度と $20^{\circ} \mathrm{C}$ 程度の 2 種類とするとともに, 練混ぜ水の温 度が $5^{\circ} \mathrm{C}$ の場合と $20^{\circ} \mathrm{C}$ の場合についてフレッシュコンク リートの性質の変化を検討した。練上りから 3 時間まで のスランプフローとスランプフローの経時変化量および 凝結時間を測定した。経時変化の測定は $20^{\circ} \mathrm{C}$ 温度下 で, 凝結時間の測定は $15^{\circ} \mathrm{C}$ と $20^{\circ} \mathrm{C}$ 2 種類の養生温度 下で実施した。

\section{3 ポンプ圧送がコンクリートの性質に及ぼす影響}

(1) 検討内容

高流動コンクリートをポンプ圧送した場合に，コンク リートの性質あるいは圧送条件などによっては，コンク リートの流動性に関わる性質とくにスランプフローが著 しく変化することが知られている ${ }^{6)}$ 。このような現象を 試験室内で再現する方法として, 静的な加圧によるポン プ圧送のシミュレーション実験が試みられている7)。そ こで, 本研究においても, ポンプ圧送によるスランプフ ローロス現象などの流動性の変化を評価するため，ま ず, 静的な加圧によるポンプ圧送のシミュレーション実 験を実施した。

一方，ポンプ圧送によりコンクリートに生ずる現象を より明らかにするためには, 実際にポンプ圧送されて性 質の変化したコンクリートを現位置で採取し，この流動 性を評価することがさらに有効であると考えた。そこ で, 実際の現場施工において, 練上り後のコンクリート 試料およびポンプ圧送して性質の変化した試料を採取 し, ビデオ映像による流動性の解析ならびにコンクリー ト中の微粒分の粒度分布状態の解析を行なうことで, 流 動性の変化の状態を把握し, この原因について考察し た。

ここで, コンクリート中の微粒分の粒度分布状態の解 析を行なったのは, 著者らが行なった水中不分離性コン 
クリートのスランプフローの経時変化に関する研究 ${ }^{8)} に$ おいて, コンクリート中の微粒分の粒度分布特性值とス ランプフローの間に密接な関係が得られたからである。

(2) ポンプ圧送のシミュレーション実験方法

静的な加圧によるポンプ圧送のシミュレーション実験 (3) -1 における実験要因を表-8 に示す。ポンプ圧送に よるスランプフローロスに影響が大きいと考えられる高 性能 $\mathrm{AE}$ 減水剂の種類・使用量, 単位水量の各配合要因 と加圧方法・加圧時間の外的要因をそれぞれ変化させ た。また, 加圧前に練り置いた場合, アジテートした場 合についての実験も行なった。

シミュレーション装置と加圧方法を図-2 に示す。こ の加圧方法は, 中川らが実施した地下連続壁用高流動コ ンクリートの長距離・高圧圧送実験 ${ }^{6}$ において, 圧送に より著しくスランプフローがロスしたコンクリートの配 管内での圧力履歴を模擬したものである。圧力は 50 $\mathrm{kgf} / \mathrm{cm}^{2}$ から $10 \mathrm{kgf} / \mathrm{cm}^{2}$ まで $10 \mathrm{kgf} / \mathrm{cm}^{2}$ ずつ段階的 に低減し, 各加力レベルにおいて 9 回ずつの脈動圧力を 加えた。さらに $50 \mathrm{kgf} / \mathrm{cm}^{2}$ から $40 \mathrm{kgf} / \mathrm{cm}^{2}$ に至る間 に 30 分間の持続圧力を加える極めて厳しい条件とし た。

結合材には 3 成分系低発熱セメントを使用し, 高性能 $\mathrm{AE}$ 減水剂にはポリカルボン酸エーテル系を基本とした が, 比較のため $\beta$-ナフタリンスルフォン酸系を使用し

表-8 ポンプ圧送シミュレーションの実験ケース

\begin{tabular}{|c|c|c|c|c|c|}
\hline \multirow{2}{*}{$\begin{array}{l}\text { 実 験 } \\
\text { ケース }\end{array}$} & \multirow{2}{*}{$\begin{array}{l}\text { 単位水量 } \\
\left(\mathrm{kg} / \mathrm{m}^{3}\right)\end{array}$} & \multicolumn{2}{|c|}{ 高性能 AE 減水剤 } & \multirow{2}{*}{ 加圧方法 } & \multirow{2}{*}{$\begin{array}{l}\text { 持 続圧力 } \\
\left(\mathrm{kgf} / \mathrm{cm}^{2}\right)\end{array}$} \\
\hline & & 種 類 & $\begin{array}{l}\text { 使用量 } \\
(C \times \%)\end{array}$ & & \\
\hline (1) & 150 & $\mathrm{SP}-\mathrm{P}$ & 1.4 & ポンピング*1 & 10 \\
\hline (2) & 150 & $\mathrm{SP}-\mathrm{P}$ & 1.4 & ポンピング & 30 \\
\hline (3) & 145 & $\mathrm{SP}-\mathrm{P}$ & 1.7 & ポンピング & 30 \\
\hline (4) & 140 & $\mathrm{SP}-\mathrm{P}$ & 1.7 & ポンピング & 30 \\
\hline (5) & 140 & $\mathrm{SP}-\mathrm{P}$ & 1.7 & ポンピング & 30 \\
\hline (6) & 140 & $\mathrm{SP}-\mathrm{P}$ & 1.7 & $\begin{array}{l}\text { 静置 } 30 \text { 分 } \\
\text { ボン゚ング }\end{array}$ & 30 \\
\hline (7) & 150 & $\mathrm{SP}-\mathrm{N}$ & 2.7 & ポンピング & 30 \\
\hline (8) & 150 & $\mathrm{SP}-\mathrm{P}$ & 1.4 & アジテート*2 & 0 \\
\hline \multicolumn{6}{|c|}{ *1 ポンピングのパターンは図-2による } \\
\hline *2 パン & 坚ミキサに。 & るアジテー & ト $(23 \mathrm{rp}$ & , 周速 $51 \mathrm{~cm}$ & \\
\hline
\end{tabular}

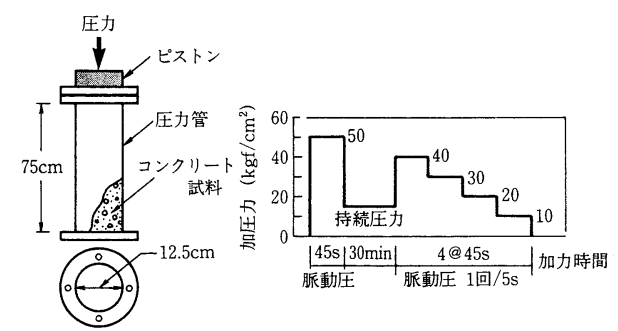

図-2 ポンプ压送シミュレーションの装置と加カパターン
た場合についても実験を行なった。単位水量と高性能 $\mathrm{AE}$ 減水剂量を試験ケースに応じて変化させた。

練上り時のスランプフローと加圧後のスランプフロー および練上りから加圧試験に要する時間のあいだ静置し たコンクリートのスランプフローを比較した。

（３）現場でポンプ圧送したコンクリートの性質の評 価

現場における測定は 2 回実施した。配管および圧送の 条件を図-3 に示す。コンクリートの配合および使用材 料は表 -7 に示したものと同様である。ただし， 2 回の 測定の実施日が異なるためコンクリートの材料ロットは 異なる。

ミキサで練り混ぜられたコンクリートは一度アジテー タで滞留した後ポンプにより大型アジテータに圧送され る。さらに大型アジテータから中継ポンプに移され長距 離を圧送される。配管長が長くまたアジテータを仲介し ているところから, 練り混ぜたコンクリートが配管先端 より排出するまで 30 分〜 40 分を要する。

コンクリートの圧送には 8 インチ管を使用した。圧送 距離は実長で $180 \mathrm{~m}$ と $240 \mathrm{~m}$ の 2 種類である。圧送距 離の小さい場合の方が圧送速度が大きいため, コンク リートが受ける圧送圧力としては前者の方が大きい。

練上り直後にミキサ下の排出ホッパから採取した 2 試 料（プラントは 2 系統独立であるため 2 台のミキサの練 上がり試料をそれぞれ採取）と中継ポンプにより圧送さ れる直前の試料（アジテー夕採取試料と称する）および 打設地点のホース先端から採取した試料（圧送後試料と 称する）の 3 種類のコンクリートについて以下に示す測 定を実施した。

1) スランプフロー速度 ; 通常のスランプフロー試験 時に, スランプコーンの抜き始めからコンクリート

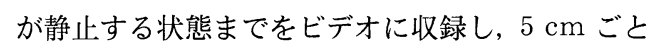
のスランプフロー時間を録画映像より計測した。そ して, この計測值から平均変形速度 $\left(V_{\mathrm{av}}\right)$ を算出 した ${ }^{9)}$ 。

$V_{\mathrm{av}}$ はコンクリートの水平方向への流動速度を ある一定の時間範囲で平均したものである。スラン プコーンの抜き始めおよび停止直前は試験によるば らつきが比較的大きいため, スランプフローが 35

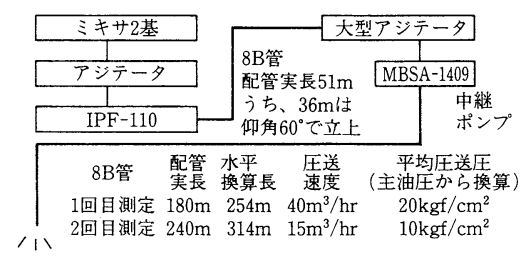

図-3 配管構成と圧送条件 
$\mathrm{cm} \sim 50 \mathrm{~cm}$ 区間での速度を対象として平均変形速 度を算出した。

2）骨材を含む微粒分の粒度分布 ; スランプフロー試 験時に採取したコンクリート試料を $5 \mathrm{~mm}$ ふるい によりウエットスクリーニングして得たモルタル試 料を，アセトン中に投入し十分攪找してセメントの 水和反応を停止させたのち現場から持ち帰り, 骨材 を含む微粒分の粒度分布を測定した。測定方法の概 要を図-4 に示す。

粒度分布測定装置により得た粒度分布特性から体 積平均径および単位容積当たりの表面積を算出し, コンクリートの流動性との関係を検討した。

3. 結合材の種類と高性能 $\mathrm{AE}$ 減水剂の種 類がコンクリートの性質に及ぼす影響

\section{1 フレッシュコンクリートの性質に及ぼす影響}

（1） スランプフローの経時変化と変形性

3 種類の低発熱セメントとポリカルボン酸エーテル系 および $\beta$-ナフタリンスルフォン酸系の高性能 $\mathrm{AE}$ 減水 剤をそれぞれ組み合わせた場合のフレッシュコンクリー トの性質を図一 5 , 図一 6 および図一7に示す。

図-5には，スランプフローおよびスランプフローの 停止時間の経時変化を示した。いずれの結合材と混和剂 の組み合わせにおいても, 練上り直後から 60 分後にか けてスランプフローが大きくなりその後は減少する傾向 にある。減少の程度は高性能 $\mathrm{AE}$ 減水剤の種類により

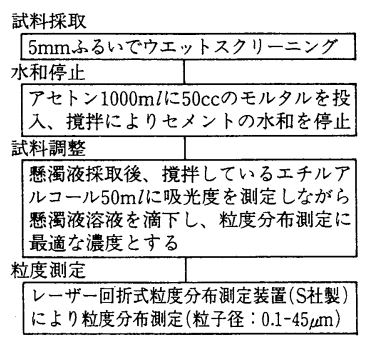

図-4 粒度分布測定方法の概要

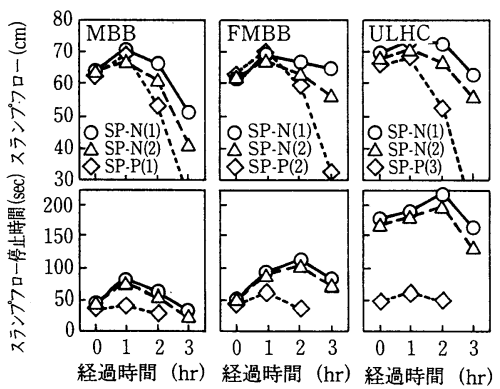

図-5スランプフローおよびスランプフローの停止時間の経 時変化
異なり, 活性持続ポリマーの少ない $\mathrm{SP}-\mathrm{N}$ (2) はこの 量の多い $\mathrm{SP}-\mathrm{N}$ (1) に比べて, $\mathrm{SP}-\mathrm{P}$ 系は $\mathrm{SP}-\mathrm{N}$ 系に 比べて，スランプフローのロスの程度が大きい。

スランプフロー停止時間の変化傾向も結合材と高性能 $\mathrm{AE}$ 減水剂の組み合わせにより異なる。 $\mathrm{SP}-\mathrm{N}$ 系で $\mathrm{MBB}, \mathrm{FMBB}$ を使用した場合, 練上り直後は $\mathrm{SP}-\mathrm{P}$ 系と同様なスランプフロー停止時間となるが, 練置き後 はこれが練上り直後と比べ大きくなる傾向にある。この コンクリートのスランプフロー停止時間の変化は練上り 後 10〜15 分程度で既に生じていることが観察された。 $\mathrm{SP}-\mathrm{P}$ 系で MBB，FMBB を使用した場合には，練置 きによるスランプフロー停止時間の変化の程度は SPN系に比べて小さく，またスランプフロー停止時間自体 も小さい傾向にある。

$\mathrm{SP}-\mathrm{N}$ 系で ULHC を使用した場合には，スランプフ ロー停止時間が極端に大きくなるのに対して, SP-P 系 と ULHC の組み合わせでは, SP-P 系で MBB, FMBB を使用した場合と同様なスランプフロー停止時間となっ ている。

図-6には，スランプフローとスランプフロー停止時 間との関係およびスランプフローと平均変形速度との関 係を示す。 $\mathrm{SP}-\mathrm{N}$ 系では, 練上り後 10〜15 分程度でコ ンクリートの変形状態が変化しているため, 練上り直後

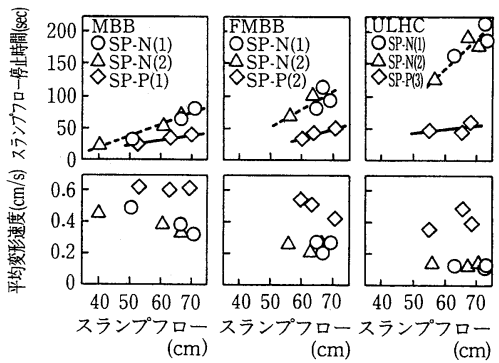

図-6 スランプフローとスランプフロー停止時間および平均 変形速度との関係

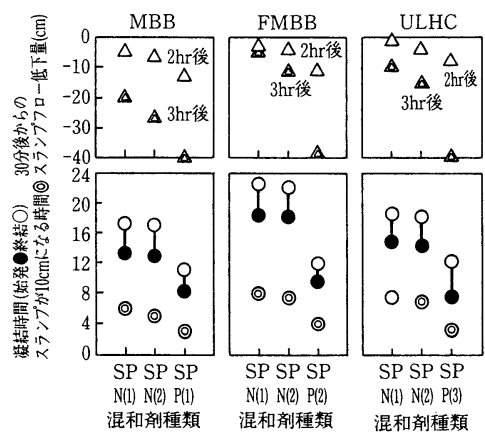

図-7疑結時間, 30 分後からのスランプフローの低下量とス ランプフローが $10 \mathrm{~cm}$ になる時間 
を除いた值の関係を示した。

スランプフローが大きくなるほどスランプフロー停止 時間が大きくなる傾向が認められるが, それぞれのスラ ンプフローの大きさに対する平均変形速度は, スランプ フローの大きさに関わらずほぼ一定となる傾向にある。 平均変形速度は, コンクリートの自重による変形性の指 標であり, 平均変形速度が小さいほど, 自重による変形 に時間を要し粘性が大きい状態であると考えられる。

$\mathrm{SP}-\mathrm{P}$ 系では, 結合材の種類による平均変形速度の 差が小さいのに対して, $\mathrm{SP}-\mathrm{N}$ 系の場合は, MBB に比 べて FMBB や ULHC での平均変形速度が小さくなっ ている。とくにULHC の場合の変形が極めて緩慢であ る。フライアッシュや粉末度の大きい高炉スラグ微粉末 と $\beta^{-}$ナフタリンスルフォン酸系高性能 $\mathrm{AE}$ 減水剤の組 み合わせが, コンクリートの平均変形速度を小さく, 粘 性を大きくしているものと考えられる。

$\mathrm{SP}-\mathrm{P}$ 系を使用すれば ULHC の場合でも変形速度は 比較的大きい。しかし, ULHC を使用したコンクリー 卜は, 練り置いたままでは粘りが大きいが外力を与える ことによって粘りが減少し流動性が良好となる, いわゆ るチクソトロピックな特徵を示すことが認められた。こ れは粉末度の大きい高炉スラグ微粉末を使用したことに よると考えられるが，ULHC を使用した配合の水結合 材比と単位水量が小さいことも影響していると推察され る。

（2）凝結時間と流動性の保持特性

前項の各配合の凝結時間と, スランプフローの経時変 化測定における練上り 30 分後からのスランプフロー低 下量およびスランプが $10 \mathrm{~cm}$ になる時間を図-7 に示 す。

$\mathrm{SP}-\mathrm{P}$ 系を使用した場合は, $\mathrm{SP}-\mathrm{N}$ 系と比較して, 凝結時間とスランプが $10 \mathrm{~cm}$ になる時間は極端に早く なる。一方, 30 分後からのスランプフローの低下量は 大きくなる傾向にある。

図-8には, 凝結始発時間と 30 分後からのスランプフ ローの低下量およびスランプが $10 \mathrm{~cm}$ になる時間との 関係を示した。凝結始発時間と 30 分後からのスランプ フローの低下量とは相関があり, 凝結時間が遅いほど長 時間流動性を保持することができると考えてよい。一 方, 凝結始発時間とスランプが $10 \mathrm{~cm}$ になる時間との 間にも関係があると考えられるが, MBB と FMBB で は, 両者が図上で同一直線上に位置するのに対して, ULHC は, 同じ凝結始発時間の MBB とFMBB に対 してスランプが $10 \mathrm{~cm}$ になる時間がやや遅れる傾向に ある。結合材の種類により凝結始発時間と自立性との関 係が変化する可能性が認められる。

(3) 高性能 AE 減水剂の成分調整によるスランプ

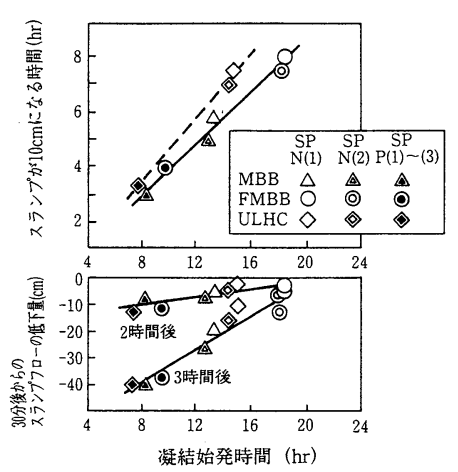

図-8 疑結始発時間と練上り 30 分後からのスランプフローの 低下量およびスランプフローが $10 \mathrm{~cm}$ になる時間との 関係

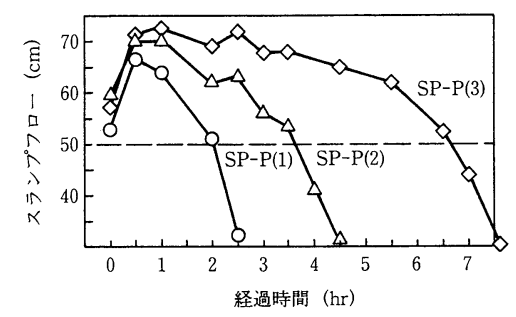

図-9 高性能 $\mathrm{AE}$ 減水剂中の架橋ポリマー量を変化させた場 合のスランプフローの経時変化

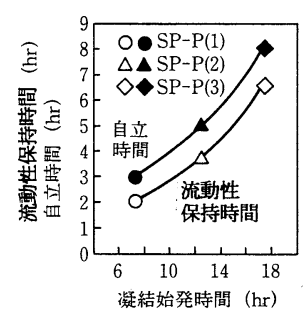

図-10 凝結始発時間と流動性保持時間および自立時間との関 係

フロー保持特性の変化

図-9には, 高性能 $\mathrm{AE}$ 減水剂中のスランプフロー保 持成分である架橋ポリマー量を変化させた場合のスラン プフローの経時変化状態を, 図-10には, 凝結始発時間 と流動性保持時間（本論文では，スランプフローが 50 $\mathrm{cm}$ となり高流動コンクリートとしての流動性が失われ るまでの時間とした）との関係および凝結始発時間と自 立時間（スランプが $10 \mathrm{~cm}$ になる時間）との関係を示 した。

高性能 $\mathrm{AE}$ 減水剂中の架橋ポリマー量を増大させる ことにより, 凝結時間が遅延しコンクリートの流動性の 保持時間が延長される。本実験では, 最長で 6 時間以上 もスランプフローを $50 \mathrm{~cm}$ 以上に保持することが可能 となっている。しかし, このように凝結を極端に遅延さ 
せスランプフローを長時間保持させた場合でも，スラン プフローが $50 \mathrm{~cm}$ となった後 1 1.5 時間のうちに, ス ランプフローが $30 \mathrm{~cm}$ 程度まで小さくなる傾向が認め られる。すなわち, ポリカルボン酸エーテル系高性能 $\mathrm{AE}$ 減水剂を使用した場合には，スランプフローの保持 時間の長短に関わらず，一定時間流動性を保持した後に コンクリートが速やかに自立する性質は保持される傾向 にある。

地下連続壁コンクリートの施工では, コンクリート は，壁体内に打ち込まれて充媜されるまでは十分な流動 性を保ち, 充填後は速やかに流動性を失い自立し側圧が 低減することが望まれる。

本節における結合材 FMBB とポリカルボン酸エーテ ル系高性能 $\mathrm{AE}$ 減水剂の組み合わせは，このような連 壁コンクリートの要求に合致したものである。また，コ ンクリートの流動性の所要時間の確保を高性能 $\mathrm{AE}$ 減 水剤中の架橋ポリマー量の調整により行なうことは, 流 動性の保持と側圧の低減の双方に極めて有効な手法であ ると考えられる。

\section{2 圧縮強度に及ぼす影響}

図-11には, 3 種類の低発熱セメントとポリカルボン 酸エーテル系および $\beta$-ナフタリンスルフォン酸系の高 性能 $\mathrm{AE}$ 減水剂をそれぞれ組み合わせた場合の圧縮強 度の発現状況を示した。

$\mathrm{MBB}$ と FMBB はほぼ同様の強度発現を示すが, ULHC では材㱓 7 日までの強度増進が大きく, 逆に 28 日から 91 日までの強度増進が小さい結果となった。 ULHC には比表面積の大きい高炬スラグ微粉末が使用 されていることが影響していると考えられる。

高性能 $\mathrm{AE}$ 減水剂の相違によっても強度の差が認め られ， $\mathrm{SP}-\mathrm{N}$ 系を使用した場合に比へてて $\mathrm{SP}-\mathrm{P}$ 系を使 用した場合の強度がより大きくなる傾向にある。

図-12 に示す圧縮強度の測定值においても， SP-P 系 の圧縮強度が $\mathrm{SP}-\mathrm{N}$ 系に比べて大きくなる傾向が認め られる。 $\mathrm{SP}-\mathrm{P}$ 系で架橋ポリマー量を調整した場合に は，凝結時間は変化するものの压縮強度には大きな变化

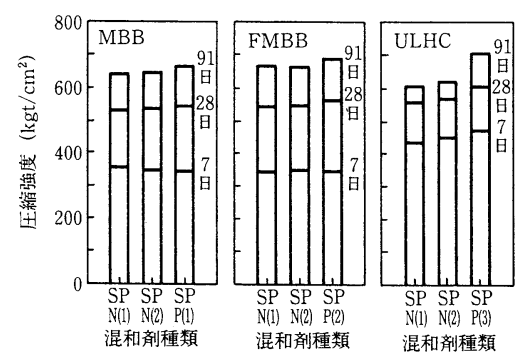

図-11低発熱セメントと高性能 AE 減水剤をそれぞれ組み合 わせた場合の圧縮強度の発現状況
は認められない。 $\mathrm{SP}-\mathrm{NM}$ は $\mathrm{SP}-\mathrm{N}$ 系と同様か若干小 さい強度を示す傾向が認められた。

セメントのロットの相違によっては, 圧縮強度の差は ほとんどなかったものの，表-9に示すように，所定の スランプフローを得るための高性能 $\mathrm{AE}$ 滅水剂が結合 材量の $0.1 \sim 0.2 \%$ も変化することが明らかとなった。

3.3 高性能 $\mathrm{AE}$ 減水剂の種類が結合材の初期水和反 応および硬化コンクリートの結合水量に及ぼす影 響

セメントペーストの初期水和発熱量の測定結果を図 -13に，硬化コンクリートの水分量と熱重量分析の測定 結果を表 -10 および表 -11 に示す。

$\mathrm{SP}-\mathrm{P}, \mathrm{SP}-\mathrm{N}, \mathrm{SP}-\mathrm{NM}$ の順に, 水和発熱のピーク が遅延する傾向が明らかである。とくに SP-NM の遅 延性が大きい。 $\mathrm{SP}-\mathrm{N}$ 系の高性能 $\mathrm{AE}$ 減水剂を使用し たコンクリートの凝結時間や流動性保持時間が $\mathrm{SP}-\mathrm{P}$ 系のものを使用した場合と比べ遅くなるのは，高性能 $\mathrm{AE}$ 減水剂の初期水和反応に与える影響が, 高性能 $\mathrm{AE}$ 減水剂の種類により異なることによるものと推察され る。 $\mathrm{SP}-\mathrm{N}$ 系の高性能 $\mathrm{AE}$ 減水剤の初期水和反応の抑 制の程度は $\mathrm{SP}-\mathrm{P}$ 系のものと比べてかなり大きいもの と考えられる。

結合水量 $\left(105 \sim 1000^{\circ} \mathrm{C}\right.$ の温度下で放出された水分

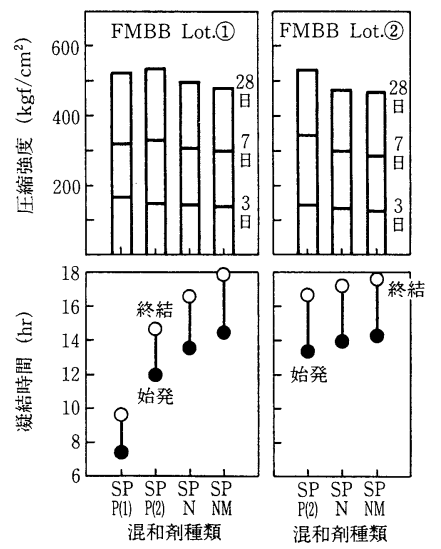

図-12 各種高性能 $\mathrm{AE}$ 減水剂を使用した場合の圧縮強度と凝 結時間の測定值

表-9 フレッシュコンクリートの試験結果

\begin{tabular}{|c|c|c|c|c|c|c|c|}
\hline \multirow{2}{*}{$\begin{array}{l}\text { 結 合 材 } \\
\text { 種 類 } \\
\end{array}$} & \multirow{2}{*}{$\begin{array}{l}\text { 混 和 剂 } \\
\text { 種 類 }\end{array}$} & \multirow{2}{*}{$\begin{array}{l}\text { 使 用 量 } \\
(C \times \%)\end{array}$} & \multicolumn{4}{|c|}{ スランプフロー $(\mathrm{cm})$} & \multirow{2}{*}{$\begin{array}{l}\text { ブリー- } \\
\text { ディング量 } \\
\left(\mathrm{cm}^{3} / \mathrm{cm}^{2}\right)\end{array}$} \\
\hline & & & 直後 & $1 \mathrm{hr}$ & $2 \mathrm{hr}$ & $3 \mathrm{hr}$ & \\
\hline \multirow[b]{2}{*}{ FMBB } & SP-P(1) & 1.7 & 55 & 65 & 51 & - & 0.02 \\
\hline & $\mathrm{SP}-\mathrm{P}(2)$ & 1.6 & 52 & 64 & 63 & 59 & 0.02 \\
\hline \multirow[t]{2}{*}{ Lot (1) } & $\mathrm{SP}-\mathrm{N}$ & 2.5 & 55 & 67 & 63 & 57 & 0.03 \\
\hline & SP-NM & 2.5 & 56 & 69 & 62 & 58 & 0.03 \\
\hline \multirow{3}{*}{ FMBB } & $\mathrm{SP}-\mathrm{P}(2)$ & 1.8 & 56 & 68 & 68 & 65 & 0.03 \\
\hline & $\mathrm{SP}-\mathrm{N}$ & 2.7 & 57 & 68 & 68 & 60 & 0.03 \\
\hline & SP-NM & 2.7 & 57 & 70 & 68 & 62 & 0.03 \\
\hline
\end{tabular}




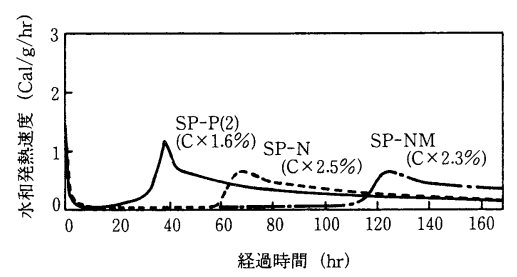

図-13 水和発熱速度の測定値

表-10 コンクリート中の水分量の測定結果

\begin{tabular}{|c|c|c|c|c|}
\hline \multirow{2}{*}{$\begin{array}{l}\text { 高性能 } \mathrm{AE} \\
\text { 減水㓱種類 }\end{array}$} & \multirow{2}{*}{$\begin{array}{l}\text { 試験前試料 } \\
\text { 乾燥重 量 } \\
\text { 減量* }(\%)\end{array}$} & 水 & \multicolumn{2}{|c|}{ 量 (\%) } \\
\hline & & $20 \sim 105^{\circ} \mathrm{C}$ & $105 \sim 1000^{\circ} \mathrm{C}$ & 合 \\
\hline SP-P & 3.3 & 1.2 & 2.5 & 3.7 \\
\hline SP-N & 3.1 & 1.1 & 2.5 & 3.6 \\
\hline SP-NM & 3.2 & 1.1 & 2.4 & 3.5 \\
\hline
\end{tabular}

$*$ 乾燥機で $105^{\circ} \mathrm{C} \cdot 48$ 時間乾燥した時の減量

表-11 熱重量分析結果

\begin{tabular}{|c|c|c|c|c|c|}
\hline 高性能A E & & 各温 & 度間の重量 & 变化 (\%) & \\
\hline 減水剂種類 & $20 \sim 105^{\circ} \mathrm{C}$ & $105 \sim 170^{\circ} \mathrm{C}$ & $170 \sim 250^{\circ} \mathrm{C}$ & $250 \sim 580^{\circ} \mathrm{C}$ & 合計 \\
\hline SP-P & 0.6 & 0.6 & 0.7 & 1.6 & 3.5 \\
\hline $\mathrm{SP}-\mathrm{N}$ & 0.5 & 0.6 & 0.7 & 1.6 & 3.4 \\
\hline SP-NM & 0.6 & 0.6 & 0.6 & 1.5 & 3.3 \\
\hline $\begin{array}{l}\text { 対応する水 } \\
\text { 和生成物 }\end{array}$ & $\begin{array}{l}\text { エトリン } \\
\text { ガイド } \\
\text { 一部 }\end{array}$ & $\begin{array}{l}\text { 石こう } \\
\text { (二水塩) }\end{array}$ & $\begin{array}{l}\text { モノサル } \\
\text { フェイト }\end{array}$ & $\begin{array}{l}\mathrm{C}-\mathrm{H}-\mathrm{S} \text { 水和 } \\
\text { 物, 水酸化力 } \\
\text { ルシウム }\end{array}$ & \\
\hline
\end{tabular}

* 示差走査熱量曲線の吸熱ピークより判断した主な水和生成物

量）の測定值および熱重量・示差熱熱曲線による水和生 成物ごとの重量変化値は，いずれの混和剤を使用した場 合でも同等であり, 高性能 $\mathrm{AE}$ 減水剂の種類によって コンクリートの水和率や水和生成物の種類が変化したと は考えにくい。

通常のセメントの強度発現性状については，一般的 に，初期に水和が遅延した場合のほうが長期的により大 きな強度增進が得られる傾向がある。しかし, 本検討や 文献 3) の事例の場合には, 初期よりもむしろ長期材龄 において高性能 $\mathrm{AE}$ 減水剂の種類による強度の差が顕 著になる傾向が認められること, また, 結合材の初期水 和反応が抑制される高性能 $\mathrm{AE}$ 減水剂を使用した場合 ほど強度が小さくなる傾向も認められることから, 高性 能 $\mathrm{AE}$ 減水剂の種類の差異により生ずる強度の差が, セ メントの水和反応の差に起因するものではなく，たとえ ば骨材の界面などコンクリート中の微小な物理的欠陥に 起因するものである可能性も考えられる。

4. 配合・製造上の要因がコンクリートの 性質に及ぼす影響

\section{1 高性能 $\mathrm{AE}$ 減水剂の使用量の影響}

図-14 には, 高性能 $\mathrm{AE}$ 減水剂の使用量を 1.45〜 $1.75 \%$ の範囲で変化させた場合のスランプフローの経

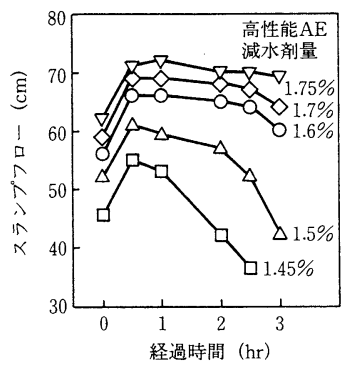

高性能AE減水剂：SP-P(ポリカルボン酸エーテル系) 結合材：3成分系低発熱セメント： $420 \mathrm{~kg} / \mathrm{m}^{3}$

図-14 高性能 AE 減水剂の使用量を変化させた場合のスラン プフローの経時変化
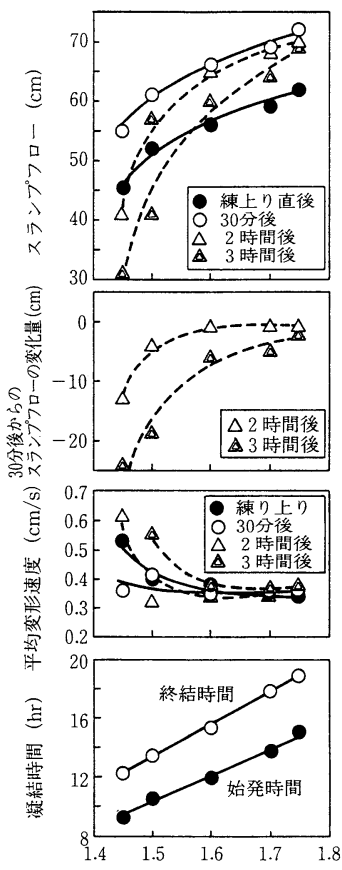

高性能AE減水剂量 $(\mathrm{C} \times \%)$

高性能AE減水剂：SP-P(ポリカルポン酸エーテル系)

結合材：3成分采低発熱セメント： $420 \mathrm{~kg} / \mathrm{m}^{3}$

図-15 高性能 $\mathrm{AE}$ 滅水剂の使用量とフレッシュコンクリート の性質との関係

時変化を, 図-15には, 高性能 $\mathrm{AE}$ 減水剂の使用量と フレッシュコンクリートの性質の関係を示した。

練上り直後から 30 分までのスランプフローの増大量 は, 高性能 $\mathrm{AE}$ 減水剂の使用量を変化させた場合で も，ほぼ一定である。これに対して 30 分後からのスラ ンプフローの低下量は, 高性能 $\mathrm{AE}$ 減水剂の使用量が 大きいほど小さくなる。凝結時間も高性能 $\mathrm{AE}$ 減水剂 の使用量が大きいほど遅延する。

スランプフロー測定時に計測したスランプフロー停止 時間をもとに算出した平均変形速度は, 高性能 $\mathrm{AE}$ 減 
水剂の使用量に関わらず，スランプフローが $55 \mathrm{~cm}$ 以 上で，ほぼ一定の值を示した。したがって，高性能 $\mathrm{AE}$ 減水凨の使用量をある程度変化させても, スランプフ ローが所定の範囲内であれば，一様なフレッシュコンク リートの変形性を保つことが可能であると考えられる。

\section{2 単位水量の変動の影響}

図一16には，単位水量 $155 \mathrm{~kg} / \mathrm{m}^{3}$ の配合において, 細骨材の表面水が-5〜 $10 \mathrm{~kg} / \mathrm{m}^{3}$ (表面水率で-0.65〜 $1.3 \%$ ）の範囲で変化した場合のフレッシュコンクリー 卜の性質と圧縮強度（材柃 28 日）の測定值を示した。

単位水量が変化することにより, 練上りスランプフ ロー, 30 分後のスランプフローとも大きく変化する。 高性能 $\mathrm{AE}$ 減水剂の使用量が $1.7 \%$ の場合, 図上で は, 表面水の変動範囲をおよそ $0.7 \%$ 程度とすること で 30 分後のスランプフローを $5 \mathrm{~cm}$ の範囲とするこ とが可能と見えるが, 単位水量が $160 \mathrm{~kg} / \mathrm{m}^{3}$ 以上の配 合では, スランプフローが $70 \mathrm{~cm}$ 以下の範囲であって も材料分離が認められた。したがって，この場合の表面 水率の管理は, 実質の単位水量が $155 \mathrm{~kg} / \mathrm{m}^{3}$ を越えな い範囲で行なう必要があると考えられる。また, 単位水 量が所定量であっても, 高性能 $\mathrm{AE}$ 減水剂が過剩で練 上り直後のスランプフローが $60 \mathrm{~cm}$ を越えるような場 合 $\left(\mathrm{SP}=1.85 \%, 155 \mathrm{~kg} / \mathrm{m}^{3}\right)$ には材料分離が生じるた め, 高性能 $\mathrm{AE}$ 減水剂の過量使用を防止し, 練上りス ランプフローを所定範囲に制御する管理を行なう必要が ある。ここで実験した配合の結合材量は $420 \mathrm{~kg} / \mathrm{m}^{3}$ で あるが, 高スランプフロー領域での材料分離に対する抵 抗性を高めるためには, 結合材量を増大させることが良

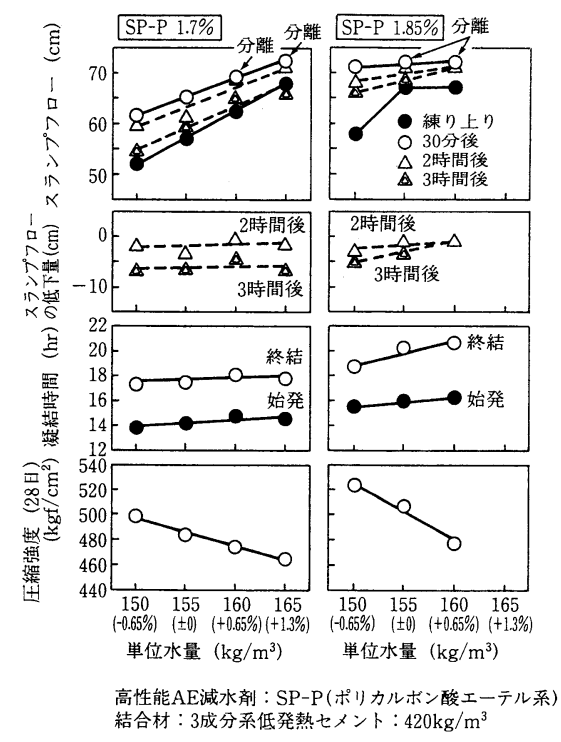

図-16 細骨材の表面水の変化がフレッシュコンクリートの性 質と圧縮強度に及ぼす影響
いと推察される。

単位水量の変化は压縮強度にも影響を及ぼす。高性能 $\mathrm{AE}$ 減水剂量が $1.85 \%$ の場合, 単位水量変動幅が士5 $\mathrm{kg} / \mathrm{m}^{3}$ (表面水率で $\pm 0.65 \%$ ) で，圧縮強度の差が 40 $\mathrm{kgf} / \mathrm{cm}^{2}$ (変動係数で約 $8 \%$ ) 程度に達している。この ように, 圧縮強度の面からも, 骨材の表面水の管理を十 分に実施する必要があることが明らかとなった。

\section{3 練上り温度の影響}

コンクリートの練上り温度がフレッシュコンクリート の性質に及ぼす影響を図一17に示す。

コンクリートの練上り温度が $11 \sim 20^{\circ} \mathrm{C}$ の範囲では, 練上りスランプフロー, 30 分後のスランプフローはほ とんど変化しない。これに対して, 30 分後から 2 時間 後あるいは 3 時間後までのスランプフローの低下量は, 練上り温度が高いほど大きくなる。これは, 練上り温度 が高いほど疑結時間が早くなることによると考えられ る。本試験では $20^{\circ} \mathrm{C}$ 以上の場合については検討しな かったが, 高温度時はスランプフローのロスに注意を払 う必要があるものと推察される。

凝結試料の養生温度を低温 $\left(15^{\circ} \mathrm{C}\right)$ として凝結試験を 行なった場合には凝結時間が著しく遅延する。この場合 は自立時間の遅れによる側圧の増大が生ずることが予想 されるため, 高性能 $\mathrm{AE}$ 減水剂のスランプフロー保持 成分量を変更するなどの対策が必要になると考えられ る。

本実験では, 練混ぜ水に冷却水を使用することを想定 して, 練混ぜ水の温度が $5^{\circ} \mathrm{C}$ 場合と $20^{\circ} \mathrm{C}$ の場合につい ても検討したが, 練混ぜ水の温度自体の影響は認められ なかった。

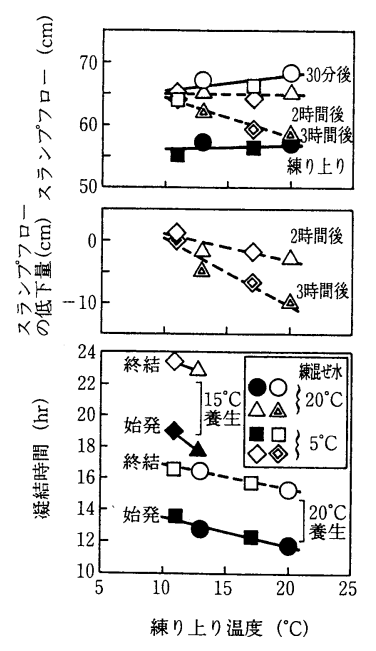

高性能AE娍水剂：SP-P(ポリカルボン酸エーテル系) 蒜合材：3成分柔低発熱セメント：420kg/ $\mathrm{m}^{3}$

図-17 コンクリートの練上り温度がフレッシュコンクリート の性質に及ぼす影響 


\section{5. ポンプ圧送がコンクリートの性質に 及ぼす影響}

\section{1 ポンプ圧送のシミュレーション実験結果}

静的な加圧によるポンプ圧送のシミュレーション実験 の結果を図-18に示す。

高性能 $\mathrm{AE}$ 減水剂の使用量が多い場合 (1.7\%) に は, 単位水量の大小, 加圧前の練り置きの有無に関わら ず, 加圧試料と静置試料間でのコンクリートの性質の相 違は全く認められなかった。これに対して, 高性能 $\mathrm{AE}$ 減水剂の使用量が少ない場合 (1.4\%) には, 加圧に よってスランプフローが減少する傾向が認められた。こ のとき持続圧力の差によってはスランプフローの減少の 程度は変化しなかった。また, 加圧によるスランプフ ローのロスは, $\beta$-ナフタリンスルフォン酸系高性能 $\mathrm{AE}$ 減水剂を使用した場合にも生じた。

本研究と同種の低発熱高流動連壁コンクリートを実際 に圧送した実験結果 ${ }^{6}$ では, 高性能 $\mathrm{AE}$ 減水剂の量が少 ないとスランプフローのロスが生じており, 本シミュ レーション実験において, 高性能 $\mathrm{AE}$ 減水剂の使用量 が少ない場合 $(1.4 \%)$ の結果は, 実際の圧送試験の結 果と傾向としては一致している。

一方, このコンクリートをパン型ミキサによりアジ テートしたところ, 20 分間のアジテートによりスラン プが $6 \mathrm{~cm}$ になるという極端なスランプフローロスが認 められた。ここで使用したパン型ミキサは, コンクリー 卜練り混ぜ用のものであり, 傾同型のアジテータと比べ 回転数が $23 \mathrm{rpm}$ と速いことから, アジテートの影響が 極端に表れたものと考えられる。

\section{2 現場でポンプ压送したコンクリートの性質の変} 化

（1）圧送によるコンクリートの変形特性の変化 2 回の現場測定における, 練上り後のコンクリート試 料とポンプ圧送した試料の, 最終スランプフローおよび スランプフローの停止時間の測定結果およびビデオ映像 の解析から算出した平均変形速度を表-12に示す。

1 回目の測定においては, 練上り時に, 2 台のミキサ の平均で $64.5 \mathrm{~cm}$ であった最終スランプフローがアジ テー夕採取時点の $62 \mathrm{~cm}$ を経て筒先では $59 \mathrm{~cm}$ と 5.5

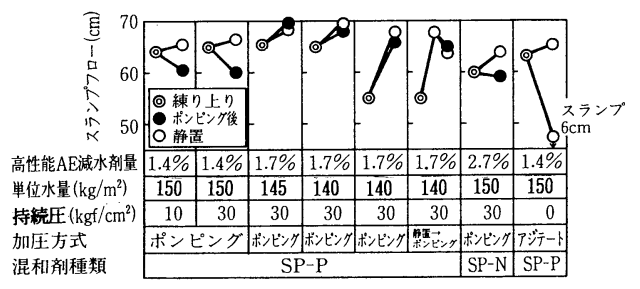

図一18 ポンプ圧送シミュレーション実験結果 $\mathrm{cm}$ 小さくなった。これに対して 2 回目の測定では, 練 上り時 $59.5 \mathrm{~cm}$ であった最終スランプフローが筒先で は $63.5 \mathrm{~cm}$ と 1 回目の計測とは逆に $4 \mathrm{~cm}$ 大きくなっ た。

コンクリートの平均変形速度の変化状態を図-19 に示 す。2 回目の圧送後の試料を除いて, 変形速度の変化傾 向はほぼ同様である。すなわち, スランプフローの初期 においては変形速度の変化が大きいが, スランプフロー が $50 \mathrm{~cm}$ 程度まで変形した後の変形速度の変化は小さ くなる傾向にある。これに対して 2 回目の圧送後の試料 は, スランプフローの最後まで大きい変形速度を保ち最 終スランプフローに近づくと急激に速度が小さくなり停 止する特徴がある。

スランプフロー速度に関する評価指標と最終スランプ フローの関係を図-20に示す。圧送前の試料では, 最終 スランプフローが大きいとスランプフロー停止時間が長 くなるが, 圧送後の試料では最終スランプフローの大き さに関わらず一定の時間で変形が停止する傾向にある。

表-12 最終スランプフローおよびスランプフロー速度の計測結果

\begin{tabular}{|c|c|c|c|c|c|c|}
\hline 測定回 & 評価指標 & $\begin{array}{l}\text { 圧送前 } \\
\text { 採取(1) }\end{array}$ & 圧送前 & $\begin{array}{ll}\vdots & \text { キサ } \\
2 & \text { 基 } \\
\text { 平 } & \text { 均 }\end{array}$ & 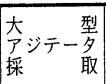 & $\begin{array}{l}\text { 圧 送 後 } \\
\text { 筒先採取 }\end{array}$ \\
\hline \multirow{6}{*}{$\begin{array}{l}1 \text { 回目 } \\
\text { 測 定 }\end{array}$} & スランプフロー $(\mathrm{cm})$ & 63.0 & 66.0 & 64.5 & 62.0 & 59.0 \\
\hline & $\mathrm{SF}$ 停止時間 （s) & 17.9 & 19.5 & 18.6 & 17.6 & 12.5 \\
\hline & $\begin{array}{r}\text { 平均変形速度 } V_{\mathrm{av}} \\
(\mathrm{cm} / \mathrm{s})\end{array}$ & 6.6 & 4.8 & 5.6 & 10.2 & \\
\hline & $1 / V_{\mathrm{av}} \quad(/ \mathrm{cm} / \mathrm{s})$ & 0.15 & 0.21 & 0.18 & 0.10 & 0.12 \\
\hline & $\begin{array}{r}\mathrm{SF} 50 \mathrm{~cm} \text { 時間 } T 50 \\
(\mathrm{~s})\end{array}$ & 3.1 & 4.1 & 3.6 & 2.2 & 2.5 \\
\hline & $\begin{array}{r}\mathrm{SF} 50 \mathrm{~cm} \text { 速度 } V 50 \\
(\mathrm{~cm} / \mathrm{s})\end{array}$ & 9.7 & 7.3 & 8.3 & 13.6 & 12.0 \\
\hline \multirow{6}{*}{$\begin{array}{l}2 \text { 回目 } \\
\text { 測 定 }\end{array}$} & スランプフロー $(\mathrm{cm})$ & 58.0 & 61.0 & 59.5 & 62.0 & 63.5 \\
\hline & $\mathrm{SF}$ 停止時間 （s) & 13.5 & 18.6 & 16.1 & 13.5 & 11.3 \\
\hline & $\begin{array}{r}\text { 平均变形速度 } V_{\mathrm{av}} \\
(\mathrm{cm} / \mathrm{s})\end{array}$ & 5.2 & 6.1 & 5.6 & 6.5 & 13.0 \\
\hline & $1 / V_{\text {av }} \quad(/ \mathrm{cm} / \mathrm{s})$ & 0.19 & 0.16 & 0.18 & 0.15 & 0.08 \\
\hline & $\begin{array}{r}\mathrm{SF} 50 \mathrm{~cm} \text { 時間 } T 50 \\
(\mathrm{~s})\end{array}$ & 4.9 & 4.0 & 4.5 & 3.8 & 1.8 \\
\hline & $\begin{array}{r}\mathrm{SF} 50 \mathrm{~cm} \text { 速度 } V 50 \\
(\mathrm{~cm} / \mathrm{s})\end{array}$ & 6.1 & 7.5 & 6.7 & 7.9 & 16.7 \\
\hline
\end{tabular}

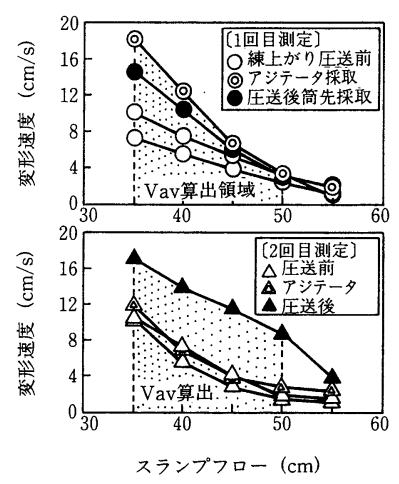

図-19 コンクリートの変形速度の変化状態 


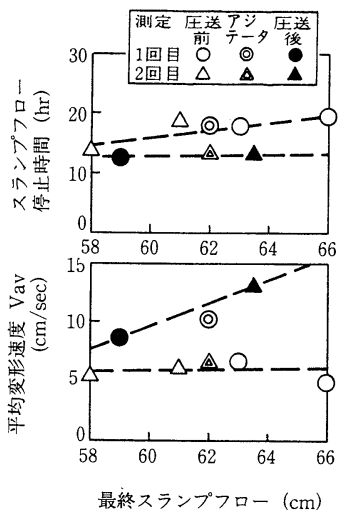

図-20 最終スランプフローとスランプフ ロー停止時間および平均変形速度の 関係

ただしこの場合, 平均変形速度は, 最終スランプフロー が大きいほど速くなる。これに対して, 圧送前の試料 は, 最終スランプフローの大きさに関わらず一定の速度 で変形する傾向にある。1 回目, 2 回目の測定試料とも この速度はほぼ同等であり, 圧送前のコンクリートの変 形性はほぼ一様であったものと推察される。

既報9)では, $V_{\mathrm{av}}$ の逆数がコンクリート中のモルタル の見かけの粘度と相関関係があり, 平均変形速度の大き いコンクリートは粘度が小さいと考えられるとしてい る。そこで図-21では, 縦軸に塑性粘度と関係する簡単 な指標として $1 / V_{\mathrm{av}}$ を, 横軸に降伏值と関係すると考 えられる簡単な指標として最終スランプフローの逆数 (1/(SF-20), SF は最終スランプフロー) を取り, コン クリートの圧送による性質の変化の説明を試みた。ここ で, $(1 /(\mathrm{SF}-20))$ を指標としたのは, コンクリートが 全く変形しない場合にスランプフローは $20 \mathrm{~cm}$ となり 降伏值が無限大になること, 水のような変形性の大きい 材料ではスランプフローが無限に大きくなり降伏值が 0 に近づくことが表現できることによるものである。

図-21 から, 練上がりスランプフローの大小や圧送後 のコンクリートのスランプフローが低下傾向となるか, あるいは増大傾向になるかに関係なく，ポンプ圧送する ことによってコンクリートの粘性が低下する傾向が認め られる。これに対して, 最終スランプフローの逆数の変 化傾向は 1 回目之 2 回目の測定では異なる。1 回目では 圧送によって最終スランプフローの逆数が大きくなる方 向に, すなわちコンクリートの降伏值が大きくなる方向 に, 2 回目では圧送によって最終スランプフローの逆数 が小さくなる, すなわち降伏值が小さくなる方向にコン クリートの特性が変化したことが推察される。

（2）圧送によるコンクリート中の微粒分の粒度分布 の変化

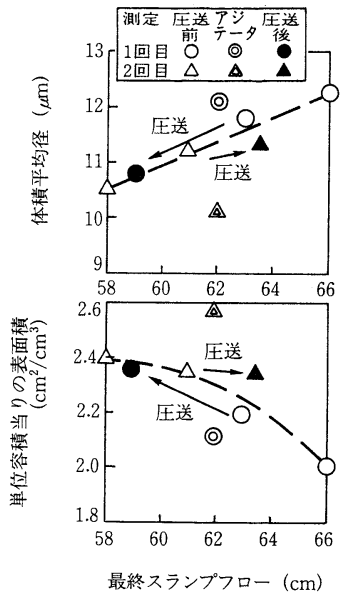

図-22 最終スランプフローと体積平均径およ び単位容積当たりの表面積の関係

\section{表-13 粒度分布の特性値}

\begin{tabular}{|c|c|c|c|c|c|c|}
\hline 測定回 & 評価指標 & $\mid \begin{array}{l}\text { 圧送前 } \\
\text { 採取(1) }\end{array}$ & $\mid$\begin{tabular}{|l|} 
压送前 \\
採取(2)
\end{tabular} & $\mid \begin{array}{ll}\Sigma & \text { キサ } \\
2 & \text { 基 } \\
\text { 平 } & \text { 均 }\end{array}$ & 採 & $\begin{array}{l}\text { 圧 送 後 } \\
\text { 筒先採取 }\end{array}$ \\
\hline 1 回目 & $\begin{array}{l}\text { 分布定数 } n^{*} \\
\text { 粒度特性值 } D e\end{array}$ & $\begin{array}{l}0.90 \\
13.4\end{array}$ & $\begin{array}{l}0.94 \\
14.0\end{array}$ & $\begin{array}{c}0.92 \\
13.7\end{array}$ & $\begin{array}{l}0.91 \\
13.8\end{array}$ & $\begin{array}{l}0.94 \\
11.3\end{array}$ \\
\hline 測 定 & $\begin{array}{l}\text { 体積平均径 }(\mu \mathrm{m}) \\
\text { 表面積 }\left(\mathrm{cm}^{2} / \mathrm{cm}^{3}\right)\end{array}$ & $\begin{array}{l}11.8 \\
2.19\end{array}$ & $\begin{array}{l}12.3 \\
2.00\end{array}$ & $\begin{array}{c}12.0 \\
2.10\end{array}$ & $\begin{array}{l}12.1 \\
2.11\end{array}$ & $\begin{array}{l}10.8 \\
2.36\end{array}$ \\
\hline 2 回目 & $\begin{array}{l}\text { 分布定数 } n^{*} \\
\text { 粒度特性值 } D \mathrm{e}\end{array}$ & $\begin{array}{l}0.98 \\
10.2\end{array}$ & $\begin{array}{l}0.90 \\
12.1\end{array}$ & $\begin{array}{c}0.94 \\
11.2\end{array}$ & $\begin{array}{l}0.92 \\
10.4\end{array}$ & $\begin{array}{l}0.89 \\
12.4\end{array}$ \\
\hline 測 定 & $\begin{array}{l}\text { 体積平均径 }(\mu \mathrm{m}) \\
\text { 表面積 }\left(\mathrm{cm}^{2} / \mathrm{cm}^{3}\right)\end{array}$ & $\begin{array}{l}10.5 \\
2.40\end{array}$ & $\begin{array}{l}11.2 \\
2.35\end{array}$ & $\begin{array}{c}10.8 \\
2.38\end{array}$ & $\begin{array}{l}10.1 \\
2.57\end{array}$ & $\begin{array}{l}11.3 \\
2.34\end{array}$ \\
\hline
\end{tabular}

表-13には，コンクリート中の微粒分の粒度分布特性 值を示した。体積平均径と単位容積当たりの表面積のそ れぞれについて, コンクリートの変形性を代表する指標 としての最終スランプフローとの関係を図一22に, 平均 変形速度との関係を図-23に示した。

アジテー夕採取試料を除いた測定結果では, 最終スラ ンプフローと体積平均径または単位容積当たりの表面積 の間には明確な関係が認められる。すなわち, 最終スラ ンプフローが大きいほどコンクリート中の微粒分の平均 径が大きく表面積が小さい傾向が認められる。

ポンプ压送による変化に着目すると, スランプフロー がロスした 1 回目の測定では, 圧送により微粒分の粒径 が小さく表面積が大きくなる傾向が明らかである。逆に スランプフローが増加した 2 回目の測定では, 圧送によ り微粒分の粒径が若干大きくなり表面積は変わらないか 若干小さくなる傾向が認められた。

図一24に示すように, 体積平均径が小さくなった場合 に表面積が大きくなる関係が明らかであるため, ポンプ 圧送によりスランプフローがロスする時には, 圧送によ り各種粒子が破碎され新たな破面が形成され表面積が大 


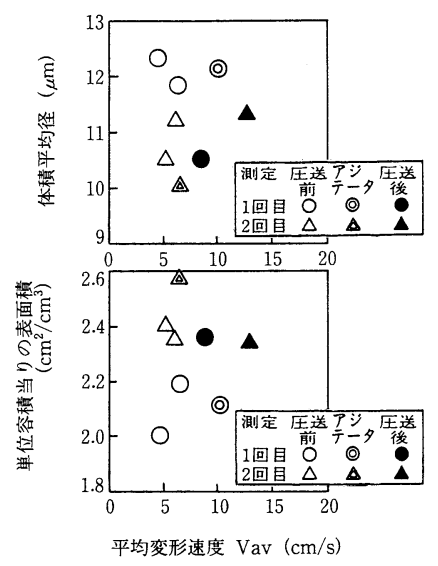

図-23 平均変形速度と体積平均径および単位容積当たりの表 面積との関係

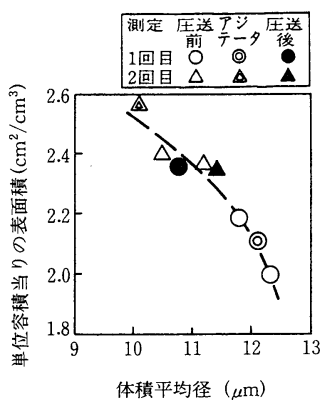

図-24 体積平均径と単位容積当たりの表面積との関係

きくなる現象が生じていることが考えられる。

一方, 平均変形速度に関しては, 体積平均径や単位容 積当たりの表面積の及ぼす影響は全く認められず，最終 スランプフローに対する場合とは異なる傾向にある。

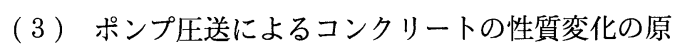
因

この種の高流動コンクリートでは, その流動性の多く を多量に添加した高性能 $\mathrm{AE}$ 減水剂の効果に依存して いる。したがって，そのスランプフローロスの現象の原 因は, 通常のコンクリートにおける脱水や空気量の低減 などの材料分離とは異なり, 圧送中の微粒分の増大に帰 着できるものと考えられる。すなわち, ポンプ圧送によ り各種粒子が破砕され新たな破面が形成されれば，その 面にコンクリート中に存在している高性能 $\mathrm{AE}$ 減水剂 が吸着することが考えられる。

本実験で用いた高性能 $\mathrm{AE}$ 減水剤には架橋ポリマー が配合されており, 時間の経過に伴い低下する高性能 $\mathrm{AE}$ 減水剂の分散性能を架橋ポリマーの加水分解によっ て生成したポリカルボン酸エーテルによって補ってい る。しかしながら, 圧送時に新たな破面を持つ微粒分が 増大する場合には，この作用が追いつかず, 結果的に液
相中の流動性の保持に奇与する実質の高性能 $\mathrm{AE}$ 減水 剂量が減少することになり最終スランプフローが低下す ることが推察される。

ポンプ圧送のシミュレーション実験においては, コン クリートに加えられる静的な圧力に比べて, 強制的なせ ん断変形によるスランプフローロスが大きいという結果 が得られている。したがって, ポンプ圧送における各種 粒子の破砕, 新たな破面の形成による高性能 $\mathrm{AE}$ 減水 剤の消費とこれに伴うスランプフローのロスには, 圧送 中の配管内でのコンクリートのせん断変形の影響が大き いことが推察される。

一方, ポンプ圧送によってコンクリートの粘性が低下 する現象に関しては, コンクリートの平均変形速度と体 積平均径や単位容積当たりの表面積といったコンクリー ト中の微粒分の粒度特性值との関係は全く認められな い。したがって, ポンプ圧送によるコンクリートの粘性 の変化は, 圧送によって最終スランプフローがロスする 現象とは異なる作用機構によるものと考えられる。その 詳細については現段階では明らかではない。

練混せ後, 静置練置きした高流動コンクリートはスラ ンプフローが増大する傾向にあり，このとき粘性は保持 されている。すなわち練置き時には高性能 $\mathrm{AE}$ 減水剂 がコンクリートの粘性に及ぼす作用は経時的に持続する 傾向にあると考えられる。一方, 使用する材料に対して 十分な量の高性能 $\mathrm{AE}$ 減水剂を添加したコンクリート を压送した場合にも最終スランプフローは増大する傾向 にある ${ }^{6)}$ 。しかし, 静置練置きしたコンクリートとポン プ圧送したコンクリートが同じ最終スランプフローを示 した場合でも，それらの流動性は同じではなく，ポンプ 圧送した高流動コンクリートは粘性の低下を伴ったもの である可能性がある。

したがって, 材料分離のない流動性に優れる地下連続 壁コンクリートをポンプ圧送により施工する場合には, ポンプ圧送によるコンクリートの性質の変化を十分考慮 する必要があると考えられる。

\section{6. 結 論}

低発熱セメントと高性能 $\mathrm{AE}$ 減水剂を組み合わせて 使用した地下連続壁用の低発熱高流動コンクリートを対 象として, 結合材の種類および高性能 $\mathrm{AE}$ 減水剂の種 類がフレッシュコンクリートの性質やコンクリートの強 度に及ぼす影響, 配合・製造上の要因がコンクリートの 性質に及ぼす影響およびポンプ圧送がコンクリートの性 質に及ぼす影響について検討した。この結果以下の結論 を得た。

（1）高炉スラグ微粉末やフライアッシュを多量に含 む低発熱セメントと $\beta^{-}$ナフタリンスルフォン酸系高性 
能 $\mathrm{AE}$ 減水剂を組み合わせた場合には, コンクリート の変形速度が小さくなる。ポリカルボン酸エーテル系高 性能 $\mathrm{AE}$ 減水剂では, 結合材の種類によらず変形速度 は一定で, ナフタリン系に比べ変形速度が大きい。

（2）粉末度の大きい高炉スラグ微粉末を大量に含む 超低発熱セメントを使用したコンクリートは, 練り置い たままでは粘りが大きいが外力を与えることによって粘 りが減少し流動性が良好となるチクソトロピックな特徴 を示す。

（３） ポリカルボン酸エーテル系高性能 $\mathrm{AE}$ 減水剂 を使用した場合, 一定の流動性を保持した後の自立時間 および凝結時間が $\beta$-ナフタリンスルフォン酸系に比べ 早い傾向にある。また, 所要時間のコンクリートの流動 性の確保を高性能 $\mathrm{AE}$ 減水剂中の架橋ポリマー量の調 整により行なうことで，一定の時間は十分な流動性を保 ち, その後は速やかに流動性を失い自立する性質を得る ことができる。

(4) 高性能 $\mathrm{AE}$ 減水剂の相違によって圧縮強度に 差が生ずる。 $\beta$-ナフタリンスルフォン酸系を使用した 場合に比べてポリカルボン酸エーテル系を使用した場合 の強度がより大きくなる傾向にある。

(5) 高性能 $\mathrm{AE}$ 減水剂の使用量をある程度変化さ せても, スランプフローが所定の範囲内であれば一様な フレッシュコンクリートの変形性を保つことが可能であ る。

（6）表面水率の管理は実質の単位水量が示方配合值 を越えない範囲で行なう必要がある。また, 材料分離を 防止するためには, 高性能 $\mathrm{AE}$ 減水剂の過量使用を防 止し, 練上りスランプフローを所定範囲に抑制する管理 を行なう必要がある。また圧縮強度の面からも骨材の表 面水の管理を十分に実施する必要がある。

（7）高流動コンクリートをポンプ圧送すると, 練上 りのスランプフローの大小あるいはポンプ圧送後のコン クリートのスランプフローが低下するかあるいは増大す るかに関わらず，コンクリートの粘性が低下する傾向が 認められる。

（８） ポンプ圧送によりスランプフローが低下したコ ンクリートにおいては, コンクリート中の骨材を含む微 粒分の粒径が小さく表面積が大きくなる傾向がある。こ れは, 圧送により各種粒子が破砕され新たな破面が形成 されるため表面積が大きくなる現象が生じていることに よると考えられる。この破面に高性能 AE 減水郕が吸 着されれば，流動性の保持に寄与する実質の高性能 $\mathrm{AE}$ 減水剤量が減少することになり，これがポンプ圧送によ るスランプフローの低下の原因になっているものと考え られる。また, 圧送中のスランプフローロスの現象に
は, コンクリートに加えられる圧力よりも, 配管内での 強制的なせん断変形の影響のほうが大きい可能性があ る。

\section{[謝辞]}

本研究の実施にあたり, 㹯エエエムビー中央研究所 守 屋慶隆, 岡沢 智, 古沢孝男, 堀部勝芳の各氏には多大 な御協力をいただきました。また，現場におけるコンク リート試料の採取にあたっては, 東京湾横断道路(㑣)川崎 工事事務所および東京湾横断道路川崎人工島東工事大成 ・飛島・五洋・ベクテル共同企業体の皆様の御協力を, また実験材料の提供においては第一セメント(㹯)の御協力 をいただきました。関係者各位に厚く感謝の意を表しま す。

\section{参考 文 献}

1）藤田信一一儀賀俊成・万木正弘・坂田 昇 : 大規模地下 連続壁のコンクリートに関する実験的研究, 土木学会論 文集, No. 435, pp. 129-138, 1991. 9

2) 児玉和已・岡沢 智 : 高強度化のための高性能 $\mathrm{AE}$ 減 水剤の開発, セメント・コンクリート, No. 546, pp. $24-32,1992.8$

3）池田秀昭 - 佐野幸洋 - 中川 修 - 鈴木健一 - 大友 健 本橋賢一：大規模地下連続壁の施工に適用するコンク リートの配合実験, 土木学会第 48 回年次学術講演会講 演概要集 V, pp. 154-155, 1993. 9

4) 横田和直・松岡康訓・大友 健・坂本 淳 : 高強度およ び早強性を有する超流動コンクリートに関する研究, 超 流動コンクリートに関するシンポジウム論文報告集, pp. 91-96, 1993. 5

5）石橋忠良・吉田彦三郎・大庭光商・竹内研一 : ポンプ圧 送による高強度コンクリート $\left(\sigma_{c k}=600 \mathrm{kgf} / \mathrm{cm}^{2}\right)$ の施 工一青森大橋 (仮称) 主塔一, コンクリート工学, Vol. 28 , No. 5 , pp. $59-70,1990.5$

6）中川 修 - 佐野幸洋 - 池田秀昭 - 鈴木健一 - 大友 健 : 高流動性地下連続壁コンクリートのポンプ圧送特性, 土 木学会第 48 回年次学術講演会講演概要集 V, pp. 156-157, 1993. 9

7) Tangtermsirikul, S., Matsuoka, Y., Shindoh, T., and Yokota, K. : A Study on Workability Loss due to Pumping of Super Workable Concrete, 土木 学会第 47 回年次学術講演会講演概要集 V, pp. 324$325,1992.9$

8) 大友 健 - 中川良隆 - 中平 淳 - 横田和直 - 松岡康訓 : 水中不分離性コンクリートの流動性を向上させる練りま ぜ方法に関する研究, コンクリートの製造システムに関 するシンポジウム論文集, pp. 1-8, 1992. 5

9) Tangtermsirikul, S., Matsuoka, Y., Shindoh, T., and Sakamoto, J. : A Study on Velocity of Deformation of Super Workable Concrete, コンクリート 工学年次論文報告集, Vol. 14, No. 1, pp. 1161-1167, 1992. 6

（原稿受理年月日 : 1993 年 7 月 12 日） 


\title{
Properties of Low-Heat and High Flowable Concrete for Underground Diaphragm Walls
}

\author{
By Takeshi Ohtomo, Kiyoshi Tanabe, Osamu Nakagawa and Masayoshi Matsukida
}

Concrete Research and Technology, Vol. 5, No. 2, July 1994

Synopsis In regard to low-Heat and high flowable concrete for underground diaphragm walls using low-Heat cement and high range water reducing and $\mathrm{AE}$ agent, the effects of kinds of binders or water reducing and $\mathrm{AE}$ agent on the properties of the concrete were examined. The effects of factors for mixture and manufacturing of concrete or of pumping on properties of the concrete were also appreciated. Based on these experiments, it was clarified that the concrete, utilized high range water reducing and AE agent of polycarboxylic acid system, has faster velocity of deformation than that of $\beta$-naphthalene sulfonic acid system and the setting time and the loss time of flowability after sufficient retention time of flowability were also faster than that one. The retention time of flowability could be controled by the quantity of cross-linking polymer in high range water reducing and $\mathrm{AE}$ agent. The viscosity of that concrete become inferior due to pumping. The reason of loss of slumpflow was considered that the quantity of high range water reducing and $\mathrm{AE}$ agent in the concrete was decreased because of adsorption of the agent to the surface of cement particles which were came from shear deformations by pumping.

Keywords : underground diaphragm walls, low-heat cement, high range water reducing and $\mathrm{AE}$ agent, flowability, setting time, pumping, slumpflow loss, particle size distribution 